\title{
Global Financial Crisis: Causes \& Consequences
}

\author{
Tanushree Gupta* \\ Assistant Professor*, Jayoti Vidyapeeth Women;s University, Jaipur
}

\begin{abstract}
The period of economic boom, a financial bubble-global in scope-has now burst. The global financial crisis, brewing for a while, really started to show its effects in the middle of 2007 and into 2008. Around the world stock markets have fallen, large financial institutions have collapsed or been bought out, and governments in even the wealthiest nations have had to come up with rescue packages to bail out their financial systems.

On the one hand many people are concerned that those responsible for the financial problems are the ones being bailed out, while on the other hand, a global financial meltdown will affect the livelihoods of almost everyone in an increasingly inter-connected world. The problem could have been avoided, if ideologues supporting the current economics models weren't so vocal, influential and inconsiderate of others' viewpoints and concerns.

The paper enlighten the facts regarding the major financial crisis like- Housing prices, Global saving glut, The financial turmoil of 2007-20, Securitization, Liquidity crisis, Mounting of oil prices and also fragment the facts of financial crisis with the help of the comparison between the average of previous recessions since 1950 to the Current recession (as of April 2009).
\end{abstract}

Key words - bailed out, financial bubble, ideologues, Mounting, Securitization.

\section{Introduction}

The financial crisis that started in the summer of 2007 and intensified in September 2008 has remade Wall Street. Financial giants such as Bear Stearns, Lehman Brothers, Merrill Lynch, AIG, FannieMae, FreddieMac, and Citigroup have either disappeared or been rescued through large government bailouts. Goldman Sachs and Morgan Stanley converted to bank holding companies in late September, marking the end of an era for investment banking in the United States While the U.S. economy initially appeared surprisingly resilient to the financial crisis, that is clearly no longer the case. The crisis that began on Wall Street migrated to Main Street. The National Bureau of Economic Research, the semi-official organization that dates recessions, determined that a recession began in December 2007. By April 2009, the unemployment rate had risen to 8.9\%, up from its low of $4.4 \%$ before the recession. Forecasters expect this rate to rise to $10 \%$ or even higher in 2010 , and it seems likely that this will go down in history as the worst recession since the Great Depression of the 1930s.

Clearly, there is a crisis among financial institutions tied to a decline in the value of their assets and the effect this has on their solvency in the presence of leverage. But the crisis has also struck household balance sheets through a decline in their assets, notably housing and the stock market.

As a result, households have cut back their consumption,

and services. Finally, the balance sheets of both the U.S. government and the Federal Reserve play starring roles in current events. The Congressional Budget Office projects that federal debt as a ratio to GDP will double over the next decade, from $41 \%$ to $82 \%$, in part because of the financial crisis.2 And the Federal Reserve has already more than doubled the size of its balance sheet, pursuing unconventional means to ensure liquidity in financial markets. In this sense, the current crisis is tightly linked to balance sheets throughout the economy for financial institutions, for households, for governments, and for the Federal Reserve. The global financial crisis in 2008 was a great event in the history of world economy

financial crisis the world has ever seen since the Great Depression in 1930s. But what are the causes of the global financial crisis? How could such a crisis happen?

The answer to this question can be summarized in just one word: greed. Greed is the factor behind all the misbehavior that eventually led to the crisis. Greed made people no longer use common sense when it comes to their financial behavior.

This could be seen easily in the subprime mortgage crisis. In normal situation, subprime mortgage any possible financial risks if the homeowner defaulted. But people wanted to make more money, 
much riskier world of subprime mortgage. They no longer thought that it was a risky business that could easily go wrong. Instead, they saw that everybody did it and the

On the other side, people were creating more and more complex financial instruments in order to make more money. No longer were they satisfied with conventional financial instruments. Instead, they created complex mathematical models upon which to create complex financial instruments like derivatives. Many people who

appropriate actions when things went wrong nor could they anticipate one.

done. Their attitude was that they would no longer be around when the problem arose. They created a dangerous instrument, but when the problem came to the surface they would no longer be involved in the deal. They had reaped their rewards and moved to something else. So who cared if things went wrong? This kind of attitudes opened the way to many irresponsible behavior in the financial world.

So there was a big bubble, a seemingly fast expansion that actually had no strong foundation. When the bubble eventually burst and caused a global financial crisis, people even economic experts were surprised. The world is near the bottom of a global recession that is causing widespread business contraction, increases in unemployment, and shrinking government revenues. Although recent data indicate the large industrialized economies may have reached bottom and are beginning to recover, for the most part, unemployment is still rising.

Numerous small banks and households still face huge problems in restoring their balance sheets, and unemployment has combined with sub-prime loans to keep home foreclosures at a high rate. Nearly all industrialized countries and many emerging and developing nations have announced economic stimulus and/or financial sector rescue packages, such as the American Recovery and Reinvestment Act of 2009 . Several countries have resorted to borrowing from the International Monetary Fund as a last resort. The crisis has exposed fundamental weaknesses in financial systems worldwide, demonstrated how interconnected and interdependent economies are today, and has posed vexing policy dilemmas. The process for coping with the crisis by countries across the globe has been manifest in four basic phases. The first has been intervention to contain the contagion and restore confidence in the system. This has required extraordinary measures both in scope, cost, and extent of government reach. The second has been coping with the secondary effects of the crisis, particularly the global recession and flight of capital from countries in emerging markets and elsewhere that have been affected by the crisis. The third phase of this process is to make changes in the financial system to reduce risk and prevent future crises. In order to give these proposals political backing, world leaders have called for international meetings to address changes in policy, regulations, oversight, and enforcement. On September 24-25, 2009, heads of the G-20 nations met in Pittsburgh to address the global financial crisis. The fourth phase of the process is dealing with political, social, and security effects of the financial turmoil. One such effect is the strengthened role of China in financial markets. The role for Congress in this financial crisis is multifaceted. While the recent focus has been on combating the recession, the ultimate issue perhaps is how to ensure the smooth and efficient functioning of financial markets to promote the general well-being of the country while protecting taxpayer interests and facilitating business operations without creating a moral hazard. In addition to preventing future crises through legislative, oversight, and domestic regulatory functions, On June 17, 2009, the Department of the Treasury presented the Obama Administration proposal for financial regulatory reform. The proposal focuses on five areas and includes establishing the Federal Reserve as a systemic risk regulator, creating a Council of Regulators, regulating all financial derivatives, creating a Consumer Financial Protection Agency, improving coordination and oversight of international financial markets, and other provisions. Treasury also has submitted to Congress proposed legislation to implement the reforms. The reform agenda now has moved to Congress. Legislation in Congress addresses many of the issues in the Treasury plan but also may focus on other financial issues. Congress also plays a role in measures to reform and recapitalize the International Monetary Fund, the World Bank, and regional development banks.

\section{Topical Shocks to the Macro economy}

What shocks to the macro economy have caused the global financial crisis? A natural place to start is with the housing market, where prices rose at nearly unprecedented rates until 2006 and then declined just as sharply. also the rise in interest rate spreads (one of the best ways to see the financial crisis in the data), the decline in the stock market, and the movement in oil prices. 


\subsection{Housing Prices}

The first major macroeconomic shock in recent years is a large decline in housing prices. In the decade leading up to 2006, housing prices grew rapidly before collapsing by more than 30 percent over the next three years.

Fueled by

ate 1990 s, by low interest rate in the 2000s, and by ever-loosening lending standards, prices increased by a factor of nearly 3 between 1996 and 2006 , an average rate of about $10 \%$ per year. Gains were significantly larger in some coastal markets, such as Boston, Los Angeles, New York, and San Francisco. Alarmingly, the national index for housing prices in the United States declined by $31.6 \%$ between the middle of 2006 and February 2009. This is remarkable because it is by far the largest decline in the index since its inception in 1987. By comparison, the next largest decline was just $7 \%$ during the 199091 recession. What caused the large rise and then sharp fall in housing prices? The answer brings us to the financial turmoil in recent years.Lured by low interest rates associated with the global saving glut, by increasingly lax lending standards, and perhaps by the belief that housing prices could only continue to rise, large numbers of borrowers took out mortgages and purchased homes between 2000 and 2006. These numbers include many soloan applications did not meet mainstream standards, for example because of poor credit records or high existing debt-to-income ratios. According to The Economist, by 2006, one fifth of all new mortgages were subprime.3 Against this background and after more than two years of exceedingly low inter-est rates, the Federal Reserve began to raise its fed funds target the rate charged for overnight loans between banks as shown in Figure 2. Between May 2004 and May 2006, the Fed raised its interest rate from $1.25 \%$ to $5.25 \%$, in part because of concerns over increases in inflation. (This was arguably a reasonable policy according to the Taylor Rule, interest rates were too low in the preceding years and the Fed raised them to a more reasonable level. This will be discussed further below.) Higher interest rates generally lead to a softening of the housing market, as borrowing becomes more costly.

In an environment with subprime borrowers facing mortgages whose rates were moving from low teaser rates to much higher market rates, the effect on housing prices was even more severe. According to Chairman Bernanke, by August 2007, nearly 16 percent of subprime mortgages with adjustable rates were in default. Since that time, the problem has spiraled as low housing prices led to defaults, which lowered housing prices even further in a vicious cycle.

\subsection{The Global Saving Glut}

this speech and see one of the main causes of the sharp rise in asset prices. The genesis of the current financial turmoil has its source, at least to some extent, in financial crises that occurred a decade ago. In this speech, Governo Bernanke noted that financial crises in the 1990s prompted an important shift in the macroeconomics of a number of developing countries, especially in Asia. Prior to the crises many of these countries had modest trade and current account deficits: essentially, they were investing more than they were saving, and this investment was financed by borrowing from the rest of the world. For rapidly growing countries, this approach has some merit: they will be richer in the future, so it makes sense to borrow now in order to maintain consumption while investing to build new highways and equip new factories. For a variety of reasons, these countries experienced a series of financial crises in the 1990s: Mexico in 1994, Asia in 1997 1998, Russia in 1998, Brazil in 1999, and Argentina in 2002

The result was a sharp decline in lending from the rest of the world, steep falls in the value of their currencies and stock markets, and significant recessions. After the crises, these countries increased their saving substantially and curtailed their foreign borrowing, instead becoming large lenders to the rest of the world especially to the United States. While developing countries on net borrowed \$88 billion in 1996 from the rest of the world, by 2003 they

ets.

Bernanke argued that this reversal produced a global saving glut: capital markets in advanced countries were awash in additional saving in search of good investment opportunities. This demand for investments contributed to rising asset markets in the United States, including the stock market and the housing market. One way this happened was through the creation of mortgage-backed securities, as we see in the next two sections.

\subsection{The Financial Turmoil of 2007-20??}

To understand the financial turmoil that followed, it helps to appreciate a (generally valuable) innovation in finance known as securitization. Like a decadent buffet at an expensive hotel, securitization involves lumping together large numbers of individual financial instruments such as mortgages and then slicing and dicing them into different pieces that appeal to different types of investors. A hedge fund may take the riskiest piece in the hope of realizing a high return. A pension fund may take a relatively safe portion, 
constrained by the rules under which it operates. The resulting pieces go by many names and acronyms, such as mortgage-backed securities, asset-backed commercial paper, and collateralized debt obligations (CDOs). In principle, combining large numbers of assets can diversify the risk associated with any individual asset

For instance, one subprime mortgage may be especially risky, but if you put thousands together and only a few default, the aggregate instrument will be mostly insulated. In the case of the subprime crisis, however, the underlying mortgages proved to be significantly riskier than most investors realized. Banks that generated the mortgages sold them off and did not have to bear the consequences if their particular mortgages went bad; as a result, lending standards deteriorated.

Moreover, securitization is based to a great extent on the supposition that a large fraction of mortgages will not go bad at the same time. After all, the history of the U.S. housing market was that while some regions experienced large declines, the overall national market was relatively stable. When the Fed raised interest rates, more and more subprime mortgages went under, housing prices fell nationwide, and this led to even more defaults. Securitization did not (and cannot) insulate investors from aggregate risk. As sophisticated financial instruments were developed and traded, it became difficult to know how much exposure an individual bank had to this risk. In August of 2007, these forces came to a head and banks sharply increased the interest rates that they charged one another: If Bank A worries that Bank B is backed by a large number of bad mortgages, it will demand a premium to lend money or may not lend at all. There was cided to place their funds in U.S. Treasury bills gov-ernment bonds that mature in one year or less, sometimes called instead of lending to other banks. As a result, the spread between T-bill yields and interbank lending rates rose dramatically. What had been a modest premium of 0.2 to 0.4 percentage points rose sharply to between 1.0 and 1.5 percentage points. If the yield on treasuries was $2.0 \%$, banks might lend to one another at $2.3 \%$ before the crisis.

Once the crisis started, these rates rose to as much as 3.5\%, and the amount of lending dropped, producing a classic example of a liquidity crisis a situation in which the volume of transactions in some financial markets falls sharply, making it difficult to value certain financial assets and thereby raising questions about the overall value of the firms holding those assets. In September 2008, the crisis intensified and the risk premium exploded from around 1.0 percentage point to more than 3.5 percentage points. Panic set in, and the end of Wall Street investment banking was high.

In the course of two weeks in September 2008, the government took over the mortgage companies FannieMae and FreddieMac, Lehman Brothers collapsed into bankruptcy, Merrill Lynch was sold to Bank of America, and the Federal Reserve organized an $\$ 85$ billion bailout of AIG. Treasury Secretary Henry Paulson and Fed Chair Ben Bernankemet with Congressional leaders to outline the $\$ 700$ billion Troubled Asset Relief Program (TARP), Financial markets declined sharply. The S\&P 500 stock price index fell by more than 50\% from its recent peak in 2007, placing it below levels from a decade earlier.

\subsection{Oil Prices}

If the decline in housing prices and the financial crisis were not enough, the economy also suffered from large movements in oil prices. After nearly two decades of relative tranquility, oil prices rose in mid-2008 to levels never seen before. These prices are. From a low of about $\$ 20$ per barrel in 2002, oil prices peaked at more than $\$ 140$ per barrel during the summer of 2008. This seven-fold increase is comparable in magnitude to the oil shocks of the1970s. Other basic commodities such as natural gas, coal, steel, corn, wheat, and rice also featured large price increases. States) was more than offset by increases in China, India, and the Middle East. Rising prices coupled with rising quantities are a classic sign of a outward shift in demand,

Then, spectacularly, oil prices declined even more sharply so that by the end of 2008 they hovered around $\$ 40$ per barrel. Why did these prices rise and then fall so sharply? It is instructive to consider the case of oil more carefully. The first fact to appreciate is that world oil consumption has increased significantly during this same period of sharply rising prices. For example, during the first half of 2008, a decline in oil consumption among OECD countries (including the United and it appears that rising demand throughout the world but especially among some rapidly growing emerging economies is a major driving force behind the increase in the prices of basic commodities. Shorter-term factors such as supply disruptions, macroeconomic volatility (in the United States, China, and elsewhere), and poor crop yields appear to have played a role in exacerbating the price movements. The economic slowdown associated with the global financial crisis then relieved this demand pressure, at least partially, which goes some way toward explaining the recent declines. Nevertheless it is difficult to justify both $\$ 140$ per barrel in the summer of 2008 and $\$ 40$ per barrel more recently as both being consistent with fundamentals; some speculative elements may have played a role as well. 


\section{Macroeconomic Outcomes}

Following the sharp increase in oil prices, the large decline in housing prices, and the ensuing financial turmoil, the macro economy entered a recession in December 2007. The recession first showed up in employment, Total nonfarm employment peaked at 138 million in 2007. Since then, more than 5.7 million jobs have been lost. The recession shows up a bit later in short-run output. As seen in Figure 7, short run output is slightly positive at the start of 2008. By the start of 2009, however, output is $3.6 \%$ below potential. The recession can also be seen in the unemployment rate in . From a low in 2007 of 4.4 percent, the unemployment rate has been rising sharply, reaching $8.9 \%$ in April 2009 and likely heading higher.

\subsection{A Comparison to Previous Recessions}

Table 1 provides an alternative perspective on the current recession. This table shows some key statistics in two ways: averaged over previous recessions going back to 1950 and for the current recession. For example, during the typical recession, GDP falls by

about $1.7 \%$. As of the first quarter of 2009 , GDP in the current recession had already fallen by $2.4 \%$. This number seems sure to worsen in the coming quarters as the recession continues. The employment measures clearly indicate that this recession is worse than usual Nonfarm employment is down by $4.2 \%$, compared with a typical fall of $2.1 \%$. Similarly, the unemployment rate in the current recession is up by 4.0 percentage points, compared with 2.5 percentage points in the average recession.

Table 1: Changes in Key Macroeconomic Variables: Previous Recessions and the Current recession.

\begin{tabular}{|lcc|}
\hline & Average of previous recessions since 1950 & Current recession (as of April 2009) \\
\hline \hline GDP & $-1.70 \%$ & $-2.40 \%$ \\
Nonfarm Employment & $-2.10 \%$ & $-4.20 \%$ \\
Unemployment Rate & 2.5 & 4 \\
Components of GDP & & \\
Consumption & $0.40 \%$ & $-1.00 \%$ \\
Investment & $-14.70 \%$ & $-25.30 \%$ \\
Government Purchases & $1.20 \%$ & $2.20 \%$ \\
Exports & $-1.50 \%$ & $-10.20 \%$ \\
Imports & $-4.40 \%$ & $-16.60 \%$ \\
\hline
\end{tabular}

Note: The current recession has recently begun to show up in GDP but is already large in terms of employment. It also features a particularly large decline in consumption. Source: The FRED database.

The remainder of Table 1 explores the components of GDP and shows an important way in which the current recession is atypical. On average during the last half century, recessions are characterized by a relatively stable level of consumption it actually rises by a small amount of $0.4 \%$ in past recessions. The severity of the current recession is already evident in consumption, which has fallen by $1.0 \%$. In most recessions, households

seek to smooth their consumption even though GDP is declining. This recession, however, has been led in part by declines in consumption itself.

One explanation for this behavior is that the large declines in housing and the stock market have reduced household wealth substantially. This is a decline in permanent income, and consumption has fallen accordingly. Investment and exports are also down sharply, much more than in the typical recession. Government purchases of goods and services is the one bright spot, having risen by a modest amount.

\subsection{Inflation}

inflation rate that excludes food and energy prices. The overall inflation rate shows a sharp swing in 2008, driven in large part by the movements in energy prices. The rise in the price of oil in the first half of the year leads the inflation rate to peak at about $5.5 \%$ in the middle of the year. The sharp decline in the price of oil actually produces a negative inflation rate by the end of 2008. As of April of 2009, the overall CPI had fallen by $0.6 \%$ over the previous twelve months. In contrast, the core inflation rate has been much smoother. Core inflation was just over $2.0 \%$ during the last several years. In the current recession, inflation has declined slightly, and the rate as of April 2009 was 1.9\%.

\section{A Comparison to Other Financial Crises}


Global Financial Crisis: Causes \& Consequences

How does the U.S. experience so far compare to outcomes in other financial crises,

Table 2: Average Outcomes of a Financial Crisis

\begin{tabular}{|l|c|}
\hline \multicolumn{1}{|c|}{ Economic Statistic } & Average Outcome \\
\hline Housing prices & $-35 \%$ \\
\hline Equity prices & $-56 \%$ \\
\hline Unemployment & +7 percentage points \\
\hline Duration of rising unemployment & 4.8 years \\
\hline Real GDP & $-9.30 \%$ \\
\hline Duration of failing GDP & 1.9 years \\
\hline Increase in real government debt & $86 \%$ \\
\hline \\
Note: Financial crises are typically quite long and very costly. Source: Carmen Reinhart and \\
Kenneth Rogoff, "The Aftermath of Financial Crises” working paper, December 2008
\end{tabular}

and what might the future hold? Carmen Reinhart and Ken Rog off have gathered dataon many of the major financial crises that have hit the world in the last century, including the Great Depression, Japan in the 1990s, Sweden in 1991, and the Asian financial crisis of

crisis affects the macroeconomy along a number of key dimensions. Their results are summarized in Table 2. The bottom line of their historical study is that financial crises are typically quite long and very costly to the economy.

For example, the unemployment rate rises on average by 7 percentage points over the course of almost 5 years, government debt nearly doubles, and real GDP declines by close to $10 \%$. While there is variation around these averages some crises are shorter and shallower while others are longer and deeper these data e in the United States. This could indicate that the current crisis will not be as severe, but it seems more likely that further declines in the real economy are coming over the next year.

\subsection{The Rest of the World}

Another important feature of the current financial crisis is that it is now global in scope. The advanced countries of the world including Japan, Germany, the U.K., and France are all in or headed for deep recessions. Recently, for example, Japan announced that GDP in the first quarter of 2009 fell at an annualized rate of more than 15\%, its sharpest decline since 1974.Figure 10 shows GDP growth for the world as a whole going back to 1990, together with forecasts by the International Monetary Fund (IMF) for 2009 and 2010. The IMF forecasts that world GDP will actually decline in 2009, falling by $1.3 \%$. The forecasts for individual countries are also grim: GDP is projected to fall by $4.0 \%$ in the Europea Union and by $6.2 \%$ in Japan. Growth in emerging markets, including China, is forecast to slow significantly. There are at least two important implications of the global nature of this financial crisis. First, it means that exports are not going to be a major source of demand for the United States or for any other country. In the 1990s, Japan could hope that demand from the rest of the world would mitigate its slump.

Such hope is not available for the world as a whole. In fact, declines in export demand from the rest of the world will likely be an important drag on GDP growth in many countries. Second, the global nature of the crisis emphasizes that this recession is markedly different from much of what has come before.

\section{Some Fundamentals of Financial Economics}

To understand the financial crisis, it is helpful to have some familiarity with several basic concepts in finance. As mentioned earlier, the current crisis is in many ways a balance sheet crisis. This section explains what a balance sheet is, how the equity or net worth of a company is determined, and the important concept of leverage and how it makes companies and individuals very sensitive to relatively small declines in asset prices.

\subsection{Balance Sheets}

Many of the basic issues involved in the financial crisis can be illuminated by focusing on the balance sheet of financial institutions, other companies, and households. As an example, consider the balance sheet of a hypothetical bank, displayed in Table 3. This hypothetical bank is modeled very loosely on the large commercial banks, like Citigroup or Bank of America.8 A balance sheet consists of two columns. On the left are 
the assets of the institution items of value that the institution owns. On the right are the liabilities items of value that the institution owes to others. In our example, the bank has three categories of assets. It has $\$ 1000$ billion of loans that it has made (such as mortgages or loans to businesses). It has $\$ 900$ billion in investments for example, the bank may own some Treasury bonds, some mortgage-backed securities, and some collateralized debt obligations. Finally, the bank has $\$ 100$ billion in cash and reserves including reserves that it is required to hold on deposit with the Federal Reserve. The total assets of the bank are therefore $\$ 2000$ billion, or $\$ 2$ trillion. On the liability side, our hypothetical bank also has three categories. The main liability of most banks are the deposits that households and businesses have made.

Table 3: A Hypothetical Bank's Balance Sheet (billions of dollars)

\begin{tabular}{|lc|lc|}
\hline \multicolumn{2}{|c|}{ Assets } & \multicolumn{2}{c|}{ Liabilities } \\
\hline loans & 1000 & Deposits & 1000 \\
\hline Investments & 900 & Short-Term Debt & 400 \\
\hline Cash \& Reserves & 100 & Long-Term Debt & 400 \\
\hline & & Total Liabilities: & 1800 \\
Total Assets & 2000 & Equity (net worth) & 200 \\
\hline
\end{tabular}

Note: The net worth of a company is the difference between its total assets and its total

liabilities. Because net worth is usually small relative to assets, a modest decline in the value of assets can render a company bankrupt.

These deposits are a liability to the bank they are funds owed to someone else. In our example the bank has $\$ 1000$ billion of deposits. It also may have borrowed funds from other financial institutions, which are another kind of liability. Here, the bank has $\$ 400$ billion in short-term debt (for example, 30-day commercial paper) and $\$ 400$ billion in long-term debt (such as 10-year corporate bonds). These liabilities total $\$ 1800$ billion. The reason this is called a balance sheet is that the two columns must balance. And the key category that makes them balance is called equity or net worth or even sometimes simply capital.

Equity is the difference between total assets and total liabilities Ssand represents the value of the insitution to its shareholders or owners (and hence is owed to someone else, which is why it is reported on the liability side of the balance sheet). In our example, the bank has a net worth of $\$ 200$ billion. Banks are subject to various financial regulations, for reasons that will become clear in a moment.

For example, a reserve requirement mandates that banks keep a certain fraction, such as 3\%, of their deposits bank. Similarly, a capital requirement mandates that the

capital (net worth) of the total assets, such as $6 \%$. For the hypothetical bank shown in Table 3, the bank appears to have about $10 \%$ of its deposits held in reserves (and cash), and capital is $10 \%(=200 / 2000)$ of total assets.

\subsection{Leverage}

Leverage is the ratio of total liabilities to net worth. For our hypothetical bank, this leverage ratio is 9 $(=1800 / 200)$. For every $\$ 10$ of assets the bank holds, $\$ 9$ is essentially financed by borrowing and only $\$ 1$ is financed by money put up by the shareholders. Leverage then magnifies any changes in the value of assets and liabilities in terms of the return to shareholders. To see why, consider what happens to our bank if it has a good year and its investments go up in value by $\$ 100 \mathrm{~b}$, from $\$ 900 \mathrm{~b}$ to $\$ 1000 \mathrm{~b}$. These investments have earned a and its equity rises from $\$ 200$ b to $\$ 300 b$. The gain of $\$ 100$ b in equity, however, represents a $50 \%$ increase! The $11 \%$ return on investments gets magnified into a $50 \%$ return to shareholders because of leverage.

The new homeowner may put $20 \%$ down and borrow $80 \%$ of the value of the new home If the house initially costs $\$ 500,000$, the homeowner starts with $\$ 100,000$ in equity in the house. Now think about what happens if the price of the house rises by $10 \%$, to $\$ 550,000$. Now the homeowner has $\$ 150,000$ of equity and has made a $50 \%$ gain on his or her investment. The reason the $10 \%$ price increase turns into a $50 \%$ gain to the homeowner is because the original investment is leveraged through the mortgage.

modest gain on a house or other investment can be turned into a huge gain

But of course there is a downside to leverage as well. In the mortgage example the downside is easy to see: if house prices fall by $10 \%$ instead of rising by $10 \%$, the homeowner loses $50 \%$ of his or her equity. 9 If prices fall by $20 \%$, the entire equity is lost. Leverage magnifies both the gains and the losses on investments. Returning to our 
bank example, suppose market prices were to fall sharply so that

instead of $\$ 900 \mathrm{~b}$. Total assets would also fall by $\$ 300 \mathrm{~b}$, to a new level of $\$ 1700 \mathrm{~b}$.

Even though the total value of assets has only fallen by $15 \%$, this change in market prices would entirely wipe worth would go from $+\$ 200$ b to $-\$ 100$ b. The assets owned by the bank would no

longer be large enough to cover the liabilities that the bank owes to others. In this situation, we say the bank is insolvent or bankrupt. When a bank or firm is highly leveraged, a given percentage change in the value of its assets has a much larger proportional effect on its net worth. This magnification is a result of leverage.

Before the financial crisis, major investment banks had leverage ratios that were even higher than in these examples.

For example, when Bear Stearns collapsed, its leverage was 35 to 1.10 Roughly speaking, the major investment banks owned complex investment portfolios, including significant quantities of soon-to-be toxic assets, that were financed with $\$ 3$ of their own equity and $\$ 97$ of borrowing. Given such extraordinary leverage, major investment banks were in a precarious position where a relatively small aggregate shock could send them over the insolvency edge.

\subsection{Bank Runs and Liquidity Crises}

Another classic version of a financial crisis that is easy to understand using balance sheets is a bank run. During the Great Depression of the 1930s, depositors worried about the possibility that banks might go under and not be able to return their deposits. At times, this led all depositors to converge on the bank at once to demand their deposits back. Looking at the balance sheet in Table 3, one can see the problem. The bank only has $\$ 100$ billion in cash and reserves on hand to repay the depositors.

in loans and investments, relatively illiquid forms that are hard to turn into cash quickly at fair value.

To repay all of its depositors, the bank may be forced to call in outstanding loans and to sell some of its investments quickly. To the extent that these actions lead the values of these assets to fall, the bank run itself may cause the bank to have negative equity, a kind of self-fulfilling prophecy In 1933, the Federal Deposit Insurance Corporation (FDIC) was set up to provide government insurance for deposits, a measure that has largely eliminated this kind of bank run.

A related problem on the liability side has occurred in the recent financial crisis, however. In this case, it is not the deposits that were the problem, but rather the short term debt.

Financial institutions often have relatively large amounts of short-term debt, in part to provide liquidity as they manage their deposits, loans, and investments. An example is commercial paper, which is often traded with maturities of one week or

the asset side of their balance sheet, which is used to manage their day-to-day commitments. In the last months of 2008 following the collapse of Lehman Brothers, financial institutions became extraordinarily worried about lending money via commercial paper to other financial institutions that might become insolvent. Interest rates on commercial paper rose sharply by more than 5 percentage points, and access to this form of liquidity was sharply curtailed. To fund their daily operations, banks may then be forced to sell some of their less liquid assets worth potentially all the way to insolvency.

\subsection{Financial Wrap-Up}

Leverage is like the genie that emerges from the magic lamp. When asset prices are rising, leverage can turn a $10 \%$ return into a $50 \%$ return. In the period leading up to the current financial crisis, the genie was granting wishes and financial institutions earned huge profits by expanding their leverage. When firms take leveraged bets that pay off 9 times out of 10, they can have long runs of seemingly amazing returns. The problem occurs when the genie inevitably catches you in a slip of the tongue.

The declines in housing prices since 2006 and the decline in the stock market have combined with leverage to threaten the solvency of many financial institutions. Because the financial system is so integrated financial institutions borrow and lend large sums with each other every day in normal times problems in a few banks can create a systemic risk for the financial system as a whole. Paul O'Neill, a former Treasury secretary under President Bush, summarized this risk with a nice analogy: if you have ten bottles of water and one is poisoned, but you don't know which, no one drinks water.

\section{REFERENCES}


9780691139296
- $\quad$ India and the G

ISBN: Publication.

$\bullet$

Verma, Feb. 2009

Studies, Dec. 2009

- $\quad$ Impact of Global Economic Dynamics on Growth of Indian Industry

- $\quad$ The

Bank of India (2009).by Dr. Narendra Jadhav
$.2011 / 06$.

paper, by John Marshall, April 22, 2009

Jaynath Verma, July 2009.

Prof. Jaynath

$\bullet$

www.iosrjournals.org

24 | Page 